\title{
Effect of the Use of Pycnanthus angolensis and Different Supplements on Yields and on the Proximate Composition of Pleurotus sajor-caju
}

\author{
Soji Fakoya, ${ }^{1}$ Abiodun Felix Adejumo, ${ }^{2}$ and Julliet Bamidele Akinyele ${ }^{2}$ \\ ${ }^{1}$ Department of Biological Sciences, Ondo State University of Science and Technology, PMB 353, Okitipupa, Ondo State, Nigeria \\ ${ }^{2}$ Department of Microbiology, Federal University of Technology, PMB 704, Akure, Ondo State, Nigeria
}

Correspondence should be addressed to Soji Fakoya; fakxoj@yahoo.com

Received 21 August 2014; Revised 25 October 2014; Accepted 3 November 2014; Published 18 November 2014

Academic Editor: Ángel Domínguez

Copyright (C) 2014 Soji Fakoya et al. This is an open access article distributed under the Creative Commons Attribution License, which permits unrestricted use, distribution, and reproduction in any medium, provided the original work is properly cited.

This study was undertaken with the aim of determining the growth, yield, and proximate composition of Pleurotus sajor-caju cultivated on Pycnanthus angolensis sawdust supplemented with 0, 5, 10, 15, and 20\% palm kernel cake (PKC), oil palm fibre (OPF), rice bran (RB), wheat chaff (WC), and corn cobs (CC). P. sajor-caju harvested produced maximum yield of $31.22 \mathrm{~g}$ on $P$. angolensis sawdust supplemented with $15 \%$ wheat chaff. The biological efficiency of substrates used ranged from $6.09 \%$ to $37.39 \%$. Results also showed a maximum crude protein of $26.33 \%$ of $P$. sajor-caju cultivated on $P$. angolensis sawdust without any supplement and fat content ranging from $0.25 \%$ to $2.21 \%$. Fibre content of harvested mushrooms ranged from $5.05 \%$ to $9.29 \%$. The study revealed that supplementing $P$. angolensis sawdust significantly influenced the growth, yield, and proximate compositions of $P$. sajor-caju.

\section{Introduction}

Mushrooms are saprophytic organisms capable of producing a wide range of enzymes that degrade the complex substrates into simple form on which they grow and absorb the soluble substrates for their own nutrition. They grow naturally on tree stumps and dead wood logs. However, the first attempt to grow this fungus for human consumption was made by Flack in 1917 in Germany. The process of cultivation on readily available substrate was taken up earlier on paddy straw in India and on sawdust in Japan [1]. This attracted attention of a number of researchers all over the world and today various species of Pleurotus are appreciated for their culinary attributes and broad adaptability under varied agroclimatic conditions.

The cultivation of edible mushrooms has evolved in time and has become an activity of economic importance in the present days, mainly for the production of species of the genera Agaricus, Pleurotus, and Lentinula. Their world production increase, especially Pleurotus spp., particularly occurred due to their ability to grow in different residues, such as sawdust and agroindustrial waste, a characteristic that made production economically viable. Such characteristics are relevant as regards production, but mushrooms are also important regarding their nutritional aspect.

The cultivation of edible mushrooms offers one of the most feasible and economic methods for the bioconversion of agrolignocellulosic wastes [2, 3]. The technology can also limit air pollution associated with burning agriculture wastes as well as decreasing environmental pollution due to unutilized agricultural wastes. However, the objectives of this research work are to investigate the effect of different supplements at varying percentage on the growth, yield, and proximate composition of Pleurotus sajor-caju cultivated on wood dusts.

\section{Materials and Methods}

2.1. Sample Collection. Sawdust of Pycnanthus angolensis was collected from saw mills in Akure metropolis. Supplements used were corn cobs (CC), oil palm fibre (OPF), wheat chaff (WC), rice bran (RB), and palm kernel cake (PKC) which were collected from oil mills and agroprocessing units in 
TABLE 1: Yield and biological efficiency of Pleurotus sajor caju cultivated on P. angolensis sawdust with different supplementation levels.

\begin{tabular}{|c|c|c|c|c|}
\hline Substrates & 1st flush (g) & 2nd flush (g) & Total yield (g) & B.E (\%) \\
\hline Control & 17.24 & 7.35 & $24.57 \pm 0.021^{\mathrm{cf}}$ & $26.34 \pm 0.57$ \\
\hline $5 \%$ OPF & 12.22 & 10.84 & $23.04 \pm 0.03^{\mathrm{b}}$ & $25.30 \pm 0.38^{\mathrm{b}}$ \\
\hline $10 \%$ OPF & 15.49 & 9.32 & $24.81 \pm 0.08^{\mathrm{d}}$ & $27.48 \pm 0.34^{\mathrm{d}}$ \\
\hline $15 \%$ OPF & 17.88 & 10.35 & $28.25 \pm 0.07^{\mathrm{e}}$ & $33.38 \pm 0.14^{\mathrm{e}}$ \\
\hline $20 \%$ OPF & 20.08 & 10.89 & $30.99 \pm 0.02^{\mathrm{f}}$ & $34.64 \pm 0.35^{f}$ \\
\hline $100 \%$ OPF & 0.00 & 0.00 & 0.00 & 0.00 \\
\hline $5 \%$ PKC & 9.89 & 5.78 & $15.48 \pm 0.17^{\mathrm{b}}$ & $16.27 \pm 0.21^{\mathrm{b}}$ \\
\hline $10 \%$ PKC & 10.33 & 7.27 & $17.64 \pm 0.03^{\mathrm{c}}$ & $16.09 \pm 0.11^{\mathrm{b}}$ \\
\hline $15 \%$ PKC & 15.98 & 10.30 & $26.23 \pm 0.05^{\mathrm{e}}$ & $29.03 \pm 0.05^{\mathrm{d}}$ \\
\hline $20 \%$ PKC & 19.98 & 11.21 & $31.20 \pm 0.01^{\mathrm{f}}$ & $36.47 \pm 0.10^{\mathrm{e}}$ \\
\hline $100 \%$ PKC & 0.00 & 0.00 & 0.00 & 0.00 \\
\hline $5 \% \mathrm{RB}$ & 9.18 & 6.00 & $15.16 \pm 0.05^{\mathrm{c}}$ & $18.83 \pm 0.09^{\mathrm{d}}$ \\
\hline $10 \% \mathrm{RB}$ & 7.77 & 3.45 & $11.22 \pm 0.01^{\mathrm{b}}$ & $13.31 \pm 0.38^{\mathrm{b}}$ \\
\hline $15 \% \mathrm{RB}$ & 10.11 & 5.20 & $15.32 \pm 0.01^{\mathrm{d}}$ & $17.28 \pm 0.26^{\mathrm{c}}$ \\
\hline $20 \% \mathrm{RB}$ & 15.89 & 6.10 & $21.99 \pm 0.01^{\mathrm{e}}$ & $22.93 \pm 0.13^{\mathrm{e}}$ \\
\hline $100 \% \mathrm{RB}$ & 4.89 & 2.90 & $7.81 \pm 0.01^{\mathrm{a}}$ & $7.53 \pm 0.24^{\mathrm{a}}$ \\
\hline $5 \% \mathrm{WC}$ & 18.87 & 10.99 & $29.81 \pm 0.11^{\mathrm{e}}$ & $31.15 \pm 0.25^{\mathrm{e}}$ \\
\hline $10 \% \mathrm{WC}$ & 15.11 & 9.19 & $24.40 \pm 0.12^{\mathrm{b}}$ & $27.08 \pm 0.09^{\mathrm{d}}$ \\
\hline $15 \% \mathrm{WC}$ & 19.99 & 11.28 & $31.22 \pm 0.04^{\mathrm{f}}$ & $37.39 \pm 0.36^{\mathrm{f}}$ \\
\hline $20 \% \mathrm{WC}$ & 18.23 & 7.71 & $25.90 \pm 0.11^{\mathrm{d}}$ & $25.11 \pm 0.18^{\mathrm{b}}$ \\
\hline $100 \% \mathrm{WC}$ & 0.00 & 0.00 & 0.00 & 0.00 \\
\hline $5 \%$ CC & 9.10 & 1.98 & $11.05 \pm 0.04^{\mathrm{e}}$ & $14.14 \pm 0.13$ \\
\hline $10 \%$ CC & 5.09 & 1.03 & $6.08 \pm 0.04^{b}$ & $8.40 \pm 0.33^{\mathrm{b}}$ \\
\hline $15 \%$ CC & 6.66 & 2.10 & $8.79 \pm 0.08^{f}$ & $9.13 \pm 0.14^{\mathrm{c}}$ \\
\hline $20 \%$ CC & 7.00 & 2.34 & $9.52 \pm 0.23^{\mathrm{d}}$ & $10.19 \pm 0.07^{\mathrm{c}}$ \\
\hline $100 \%$ CC & 4.82 & 0.00 & $4.73 \pm 0.22^{\mathrm{a}}$ & $6.09 \pm 0.12^{\mathrm{a}}$ \\
\hline
\end{tabular}

OPF: oil palm fibre, PKC: palm kernel cake, RB: rice bran, WC: wheat chaff, CC: corn cobs, B.E: biological efficiency.

Values are means of triplicates \pm SD. Values in the same column carrying the same superscript are not significantly different according to Duncan's multiple range test at $(P \leq 0.05)$.

Akure, Ondo state. Calcium carbonate $\left(\mathrm{CaCO}_{3}\right)$ was bought from a local laboratory reagents retailer in Akure, Ondo State. Pleurotus sajor caju was obtained from the Forestry Research Institute of Nigeria, Ibadan, Oyo State, and cellular expansion was carried out to generate mycelium on Potato Dextrose Agar (PDA). However, the spawn used for the control experiment was obtained from Federal Institute of Industrial Research, Oshodi (FIIRO), Lagos, Nigeria.

2.2. Spawn Preparation. Sorghum grains were used to prepare the mother spawn. Sorghum grains were parboiled in water bath for 10-15 minutes in the ratio of 1:1 (Sorghum grains: water) and mixed with $4 \%(\mathrm{w} / \mathrm{w}) \mathrm{CaCO}_{3}$. Sorghum grains were then packed $(250 \mathrm{~g})$ in polythene bags (of $200 \times$ $300 \mathrm{~mm}$ size) and sterilized in an autoclave at $121^{\circ} \mathrm{C}$ for 30 minutes. After sterilization, the bags were inoculated under aseptic conditions with actively growing mycelium of the P. sajor caju from Potato Dextrose Agar (PDA) plates and incubated (at $27 \pm 2^{\circ} \mathrm{C}$ ) for mycelial growth without any light for 10-15 days until the mycelium fully covered the grains [4].

2.3. Cultivation of Pleurotus sajor-caju. The substrates were sterilized and allowed to cool in an inoculating chamber where inoculation of the substrates with spawn was carried out. This was followed by incubation at $25 \pm 2^{\circ} \mathrm{C}$ with relative humidity ranging around $85 \%$ in a wooden box $(1.4 \mathrm{~m} \times$ $0.8 \mathrm{~m} \times 0.5 \mathrm{~m})$ with an open and close roof system. The relative humidity, temperature, and light intensity were monitored for the period of cultivation. The plastic containers were pierced severally with sterile object as soon as the substrates were fully colonized (about 28-30 days) by the mycelium to give room for fruiting. Parameters like biomass of the fruiting bodies were monitored and recorded accordingly.

2.4. Substrate Preparation. The sawdust of Pycnanthus angolensis was soaked in water, excess water being squeezed out. $\mathrm{CaCO}_{3}(1 \%)$ and the various additives were thoroughly mixed with the sawdust at $0,5,10,15$, and $20 \% .200 \mathrm{~g}$ of each mixture was put in polythene bags, sterilised in an autoclave for 2 hours at $121^{\circ} \mathrm{C}$, allowed to cool, and inoculated with the spawn under aseptic conditions. Incubation followed in the dark.

2.5. Determination of Proximate Composition. Protein, fat, fibre, ash, and total carbohydrate were determined with the procedure recommended by [5]. 
TABLE 2: Proximate composition of dried Pleurotus sajor caju cultivated on P. angolensis sawdust with different supplement Levels.

\begin{tabular}{|c|c|c|c|c|c|}
\hline Substrate & Fat (\%) & Fibre (\%) & Ash (\%) & Protein (\%) & Carbohydrate (\%) \\
\hline Control & $1.07 \pm 0.06^{\mathrm{abd}}$ & $6.22 \pm 0.02^{\mathrm{bc}}$ & $5.38 \pm 0.15$ & $26.33 \pm 0.11$ & $61.24 \pm 0.09^{\mathrm{ab}}$ \\
\hline $5 \% \mathrm{OPF}$ & $2.08 \pm 0.08^{\mathrm{e}}$ & $8.80 \pm 0.10^{\mathrm{d}}$ & $6.63 \pm 0.27^{\mathrm{d}}$ & $22.04 \pm 0.04^{\mathrm{d}}$ & $60.22 \pm 0.19^{c}$ \\
\hline $10 \%$ OPF & $1.82 \pm 0.02^{\mathrm{c}}$ & $8.25 \pm 0.05^{\mathrm{c}}$ & $7.70 \pm 0.14^{\mathrm{e}}$ & $21.26 \pm 0.06^{\mathrm{c}}$ & $60.92 \pm 0.12^{\mathrm{d}}$ \\
\hline $15 \%$ OPF & $1.96 \pm 0.02^{\mathrm{d}}$ & $9.23 \pm 0.06^{\mathrm{e}}$ & $8.32 \pm 0.19^{f}$ & $24.08 \pm 0.05^{\mathrm{e}}$ & $56.42 \pm 0.21^{\mathrm{b}}$ \\
\hline $20 \% \mathrm{OPF}$ & $2.21 \pm 0.01^{\mathrm{f}}$ & $8.32 \pm 0.03^{c}$ & $6.30 \pm 0.15^{\mathrm{c}}$ & $20.25 \pm 0.05^{\mathrm{b}}$ & $62.85 \pm 0.14^{\mathrm{f}}$ \\
\hline $100 \%$ OPF & 0.00 & 0.00 & 0.00 & 0.00 & 0.00 \\
\hline $5 \% \mathrm{PKC}$ & $2.10 \pm 0.01^{\mathrm{d}}$ & $6.25 \pm 0.05^{\mathrm{b}}$ & $9.30 \pm 0.02^{\mathrm{e}}$ & $18.22 \pm 0.03^{b}$ & $64.23 \pm 0.10^{\mathrm{e}}$ \\
\hline $10 \%$ PKC & $2.04 \pm 0.04^{\mathrm{d}}$ & $8.83 \pm 0.05^{\mathrm{d}}$ & $9.25 \pm 0.27^{\mathrm{e}}$ & $19.86 \pm 0.05^{\mathrm{d}}$ & $60.29 \pm 0.12^{\mathrm{b}}$ \\
\hline $15 \%$ PKC & $1.09 \pm 0.02^{b}$ & $7.99 \pm 0.02^{c}$ & $8.66 \pm 0.01^{\mathrm{d}}$ & $20.11 \pm 0.11^{\mathrm{e}}$ & $62.30 \pm 0.21^{\mathrm{d}}$ \\
\hline $20 \%$ PKC & $1.36 \pm 0.06^{\mathrm{c}}$ & $6.25 \pm 0.05^{\mathrm{b}}$ & $8.08 \pm 0.01^{\mathrm{c}}$ & $19.41 \pm 0.03^{c}$ & $64.75 \pm 0.24^{\mathrm{f}}$ \\
\hline $100 \%$ PKC & 0.0 & 0.00 & 0.00 & 0.00 & 0.00 \\
\hline $5 \% \mathrm{RB}$ & $1.11 \pm 0.11^{\mathrm{b}}$ & $5.05 \pm 0.05^{\mathrm{a}}$ & $9.27 \pm 0.07^{\mathrm{cd}}$ & $20.22 \pm 0.24^{\mathrm{b}}$ & $64.18 \pm 0.02^{c}$ \\
\hline $10 \% \mathrm{RB}$ & $1.64 \pm 0.06^{\mathrm{e}}$ & $6.35 \pm 0.07^{\mathrm{c}}$ & $9.29 \pm 0.02^{\mathrm{d}}$ & $19.02 \pm 0.02^{\mathrm{a}}$ & $63.45 \pm 0.21^{\mathrm{b}}$ \\
\hline $15 \% \mathrm{RB}$ & $0.98 \pm 0.03^{\mathrm{a}}$ & $5.12 \pm 0.02^{\mathrm{a}}$ & $9.13 \pm 0.11^{b c}$ & $18.88 \pm 0.08^{\mathrm{a}}$ & $64.73 \pm 0.23^{\mathrm{d}}$ \\
\hline $20 \% \mathrm{RB}$ & $1.23 \pm 0.04^{c}$ & $7.31 \pm 0.08^{\mathrm{d}}$ & $9.02 \pm 0.02^{\mathrm{b}}$ & $21.34 \pm 0.03^{\mathrm{c}}$ & $61.16 \pm 0.13^{\mathrm{a}}$ \\
\hline $100 \% \mathrm{RB}$ & $1.37 \pm 0.05^{\mathrm{d}}$ & $5.40 \pm 0.12^{\mathrm{b}}$ & $9.01 \pm 0.03^{\mathrm{b}}$ & $20.18 \pm 0.05^{\mathrm{b}}$ & $64.10 \pm 0.10^{c}$ \\
\hline $5 \% \mathrm{WC}$ & $2.11 \pm 0.09^{f}$ & $7.96 \pm 0.06^{\mathrm{e}}$ & $6.86 \pm 0.04^{\mathrm{d}}$ & $21.60 \pm 0.15^{\mathrm{e}}$ & $61.22 \pm 0.04^{\mathrm{b}}$ \\
\hline $10 \% \mathrm{WC}$ & $1.66 \pm 0.05^{\mathrm{c}}$ & $6.92 \pm 0.06^{c}$ & $6.21 \pm 0.03^{c}$ & $18.95 \pm 0.03^{b}$ & $66.29 \pm 0.05^{\mathrm{e}}$ \\
\hline $15 \% \mathrm{WC}$ & $1.82 \pm 0.04^{\mathrm{d}}$ & $6.83 \pm 0.15^{\mathrm{c}}$ & $6.76 \pm 0.10^{\mathrm{d}}$ & $19.16 \pm 0.03^{c}$ & $65.61 \pm 0.10^{\mathrm{d}}$ \\
\hline $20 \% \mathrm{WC}$ & $1.98 \pm 0.02^{\mathrm{e}}$ & $7.71 \pm 0.11^{\mathrm{d}}$ & $6.20 \pm 0.03^{c}$ & $19.89 \pm 0.04^{\mathrm{d}}$ & $64.19 \pm 0.02^{c}$ \\
\hline $100 \% \mathrm{WC}$ & 0.00 & 0.00 & 0.00 & 0.00 & 0.00 \\
\hline $5 \% \mathrm{CC}$ & $0.72 \pm 0.03^{b}$ & $9.21 \pm 0.11^{\mathrm{e}}$ & $8.20 \pm 0.18^{f}$ & $21.07 \pm 0.04^{\mathrm{a}}$ & $60.37 \pm 0.16^{\mathrm{d}}$ \\
\hline $10 \%$ CC & $0.98 \pm 0.07^{\mathrm{c}}$ & $8.03 \pm 0.05^{b}$ & $7.29 \pm 0.02^{\mathrm{c}}$ & $21.67 \pm 0.18^{b}$ & $62.24 \pm 0.08^{f}$ \\
\hline $15 \%$ CC & $1.00 \pm 0.04^{\mathrm{c}}$ & $9.29 \pm 0.05^{\mathrm{e}}$ & $7.00 \pm 0.03^{b}$ & $24.32 \pm 0.11^{\mathrm{d}}$ & $58.52 \pm 0.22^{c}$ \\
\hline $20 \%$ CC & $1.27 \pm 0.05^{\mathrm{e}}$ & $9.03 \pm 0.03^{d}$ & $7.67 \pm 0.20^{\mathrm{d}}$ & $23.75 \pm 0.25^{\mathrm{c}}$ & $58.29 \pm 0.05^{\mathrm{b}}$ \\
\hline $100 \%$ CC & $0.25 \pm 0.03^{\mathrm{a}}$ & $8.21 \pm 0.18^{\mathrm{c}}$ & $7.94 \pm 0.10^{\mathrm{e}}$ & $25.99 \pm 0.03^{\mathrm{e}}$ & $57.49 \pm 0.05^{\mathrm{a}}$ \\
\hline
\end{tabular}

OPF: oil palm fibre, PKC: palm kernel cake, RB: rice bran, WC: wheat chaff, CC: corn cobs. Values are means of triplicates \pm SD.

Values in the same column carrying the same superscript are not significantly different according to Duncan's multiple range test at $(P \leq 0.05)$.

2.6. Statistical Analysis. The results obtained were statistically analysed using analysis of variance (ANOVA) and tests of significance were carried out by Duncan's multiple range test at $P \leq 0.05$.

\section{Results and Discussion}

This research revealed that the growth and yield of $P$. sajor caju were greatly influenced by the different levels of supplementation. The results in Table 1 revealed the yield and biological efficiency of the $P$. sajor-caju cultivated on Pycanthus angolensis sawdust alone (control experiment) or in combination with the supplements. The maximum yield $(31.22 \mathrm{~g})$ of $P$. sajor-caju was obtained when it was cultivated on $P$. angolensis sawdust supplemented with $15 \%$ wheat chaff while the least yield ( $4.73 \mathrm{~g}$ ) was recorded when cultivated on $100 \%$ corn cobs. The biological efficiency ranged from $6.09 \%$ to $37.39 \%$ for $100 \%$ corn cobs and P. angolensis sawdust supplemented with $15 \%$ wheat chaff, respectively. The poor growth and yield of some of the P. sajor caju cultivated might be due to inadequate nutrients that support their growth as well as the nature of the lignocelluloses present coupled with their synergistic enzymatic activities [6]. The type of substrate, the environmental conditions, and the fungus species used in cultivation all have a large influence on the growth and chemical composition of fruiting bodies [7]. Yield of mushrooms harvested from the first flush was greater than that of the second flush. This was probably due to the gradual depletion in the essential nutrients and substances needed for mushroom growth and development.

From this research, supplements such as oil palm fibre, wheat chaff, and palm kernel cake when used $100 \%$ did not favour the growth of the mushroom as the mycelium did not produce fruiting bodies. This was also reported by [8]. The slow spawn running and no fruit body production of mushroom due to $100 \%$ oil palm fibre were attributed to its high water holding capacity, difference in type of substrate, high oil content of the fibre, lack of nitrogen to balance the $\mathrm{C} / \mathrm{N}$ ratio, and the lime to maintain the $\mathrm{pH}$ [9]. However, the results of this study (on $100 \%$ oil palm fibre) do not agree with the findings of [10], who reported that species of Pleurotus complete the spawn in at least 20 days and fruit body formation in 27 days on oil palm fibre.

The protein, fat, carbohydrate, and crude fibre contents of matured and harvested fruiting bodies of $P$. sajor-caju cultivated on the different substrates combination are shown in Table 2. P. sajor-caju fruiting bodies cultivated on P. angolensis sawdust possessed the highest protein content of $26.33 \%$ 
while the lowest protein content was obtained from that cultivated on $P$. angolensis supplemented with 5\% palm kernel cake. The lowest fat content of $P$. sajor-caju was $0.25 \%$ grown on $100 \%$ corn cobs while the highest fat content $(2.21 \%)$ was obtained from that cultivated on $P$. angolensis sawdust supplemented with $20 \%$ oil palm fibre as the high oil content of the oil palm fibre might be responsible for this. The protein and fat contents recorded in this research were similar as reported in earlier studies [11, 12]. Maximum carbohydrate content of $P$. sajor-caju was $66.29 \%$ in fruiting bodies cultivated on $P$. angolensis sawdust supplemented with $10 \%$ wheat chaff while a least value of $56.42 \%$ was observed when cultivated on $P$. angolensis sawdust supplemented with $15 \%$ oil palm fibre. These results conformed to findings of [13-15]. The maximum ash content of $P$. sajor-caju was $9.3 \%$ while a minimum value of $5.38 \%$ was observed. Similar results were reported by [16].

\section{Conclusion}

Commercial production of Pleurotus mushrooms is largely determined by the availability and utilization of cheap materials of which agricultural lignocellulosic waste represents the ideal and most promising substrates for cultivation. The substrates used in this study can be considered practically and economically feasible due to their availability throughout the year at little or no cost in large quantities. The results obtained in this research work therefore showed reasonable yields in the production of bigger and more nutritious mushrooms which can serve as substitute to meat and fish. Also, the proximate composition of the mushroom obtained was rich and substantially important for human nutrition and health. However, the utilization of these agrowastes for the production of oyster mushrooms could therefore be economically and ecologically practicable.

\section{Conflict of Interests}

The authors declare that there is no conflict of interests regarding the publication of this paper.

\section{References}

[1] R. N. Verma, "Recent advances in mushroom research in India," in Advances in Mushroom Biology and Production, R. D. Rai, B. L. Dhar, and R. N. Verma, Eds., pp. 1-30, Mushroom Society of India NCRM, Solan, India, 1998.

[2] Z. Bano, M. N. Shashirekha, and S. Rajarathnam, "Improvement of the bioconversion and biotransformation efficiencies of the oyster mushroom (Pleurotus sajor-caju) by supplementation of its rice straw substrate with oil seed cakes," Enzyme and Microbial Technology, vol. 15, no. 11, pp. 985-989, 1993.

[3] R. Cohen, L. Persky, and Y. Hadar, "Biotechnological applications and potential of wood-degrading mushrooms of the genus Pleurotus," Applied Microbiology and Biotechnology, vol. 58, no. 5, pp. 582-594, 2002.

[4] C. Sánchez, "Cultivation of Pleurotus ostreatus and other edible mushrooms," Applied Microbiology and Biotechnology, vol. 85, no. 5, pp. 1321-1337, 2010.
[5] AOAC, Official Methods of Analysis, Association of Official Analytical Chemist, Airlington, Va, USA, 16th edition, 2006.

[6] P. Oei, Mushroom Cultivation with Special Emphasis on Appropriate Techniques for Developing Countries, Tool Publications, Leiden, The Netherlands, 2003.

[7] P. G. Miles and S. T. Chang, Mushroom Biology, World Scientific Press, Hong Kong, 1997.

[8] C. I. Onuoha, U. Ukaulor, and B. C. Onuoha, "Cultivation of Pleurotus pulmonarius using some agrowaste materials," Agricultural Journal, vol. 4, no. 2, pp. 109-112, 2009.

[9] M. Saidu, M. R. Salim, and M. A. M. Yuzir, "Cultivation of oyster mushroom (Pleurotus spp.) on palm oil mesocarp fibre," African Journal of Biotechnology, vol. 10, no. 71, pp. 15973-15976, 2011.

[10] I. Ahmed, Some studies on oyster mushroom (Pleurotus spp) on waste material for corn industry [M. Sc. thesis], University of Agriculture, Faisalabad, Pakistan, 1996.

[11] S. S. Patill, R. M. Kadam, S. L. Shinde, and S. A. Deshmukh, "Effect of different substrate on productivity and proximate composition of P. florida," International Journal of Plant Science, vol. 3, no. 1, pp. 151-153, 2008.

[12] S. S. Patil and H. G. Dakore, "Comparative study on yield performance and nutritive value of oyster mushroom on soybean straw," BIOINFOLET, vol. 4, no. 1, pp. 57-59, 2007.

[13] M. Bonatti, P. Karnopp, H. M. Soares, and S. A. Furlan, "Evaluation of Pleurotus ostreatus and Pleurotus sajor-caju nutritional characteristics when cultivated in different lignocellulosic wastes," Food Chemistry, vol. 88, no. 3, pp. 425-428, 2004.

[14] S. Sharma and M. Madan, "Microbial protein from leguminous and non-leguminous substrates," Acta Biotechnologica, vol. 13, no. 2, pp. 131-139, 1993.

[15] N. I. Singh, T. C. Singh, and M. B. Devi, "Nutritional composition, processing and preservation of the edible mushroom found in Manipur for sustainable economic development," Journal of Mycological Research, vol. 41, no. 2, pp. 243-244, 2003.

[16] M. H. El-Kattan, Z. A. Helmy, H. Abdel, M. El-Leithy, and K. A. Abdelkawi, "Studies on cultivation techniques and Chemical composition of Oyster mushrooms," Mushroom Journal for Tropics, vol. 11, no. 314, pp. 59-66, 1991. 

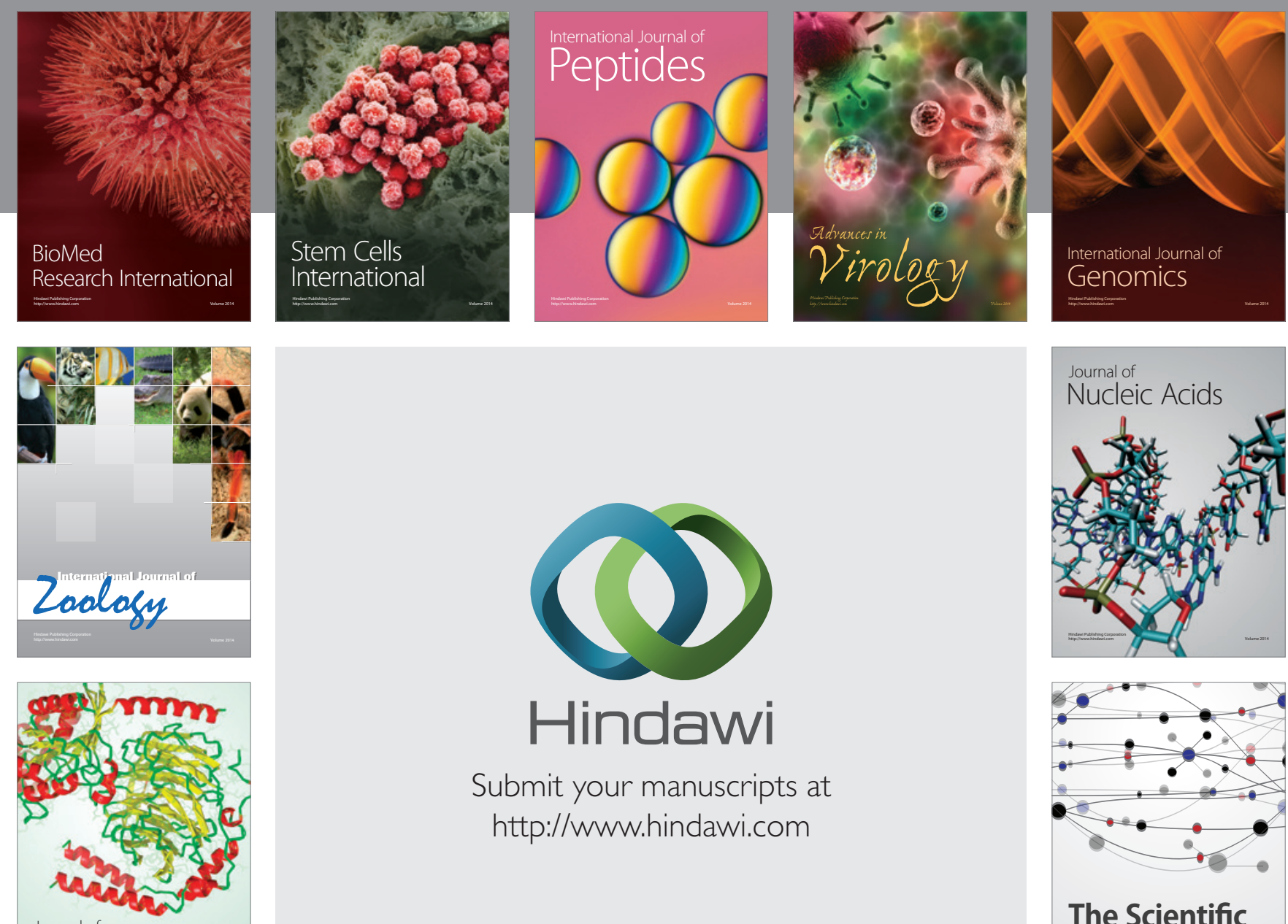

Submit your manuscripts at

http://www.hindawi.com

Journal of
Signal Transduction
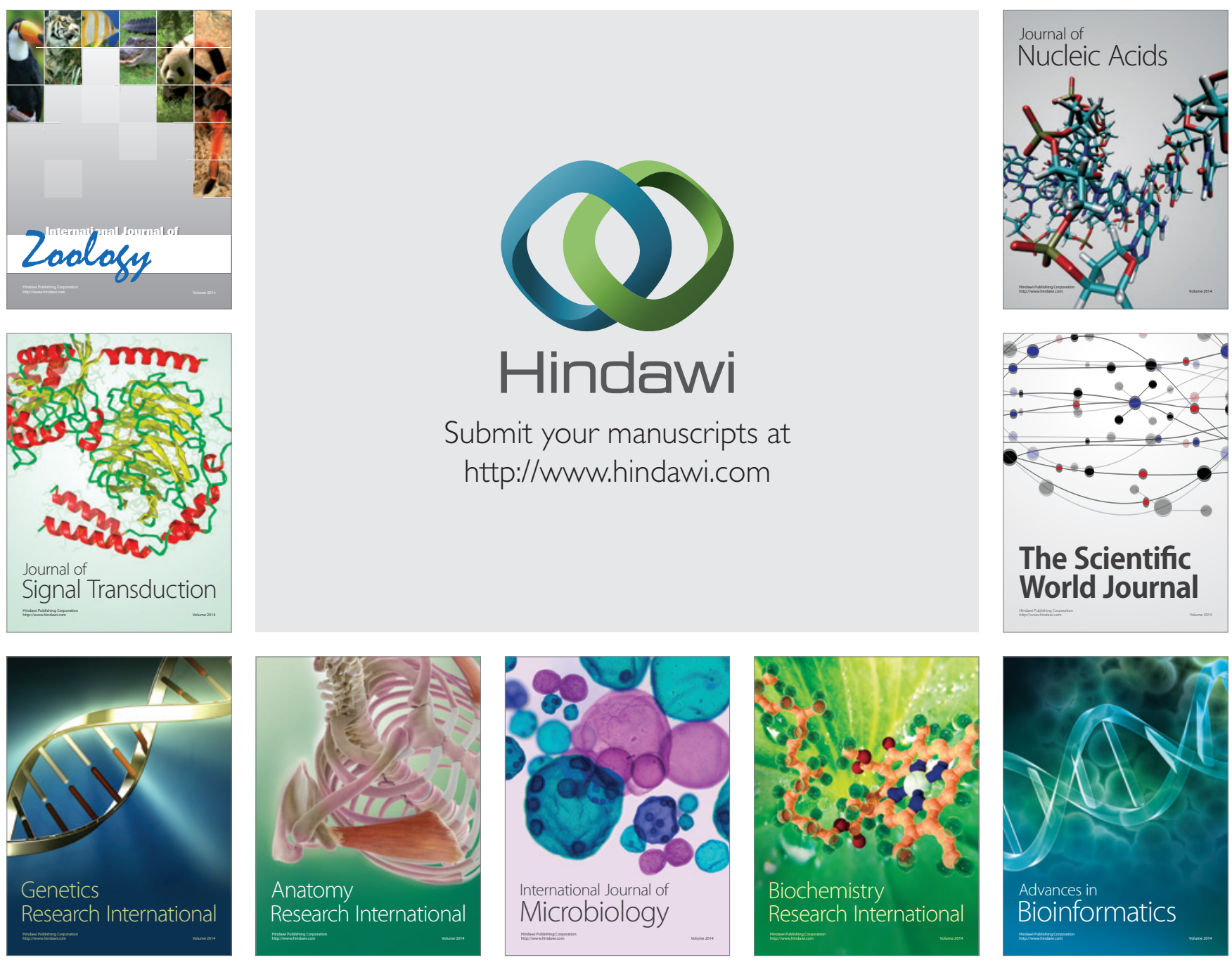

The Scientific World Journal
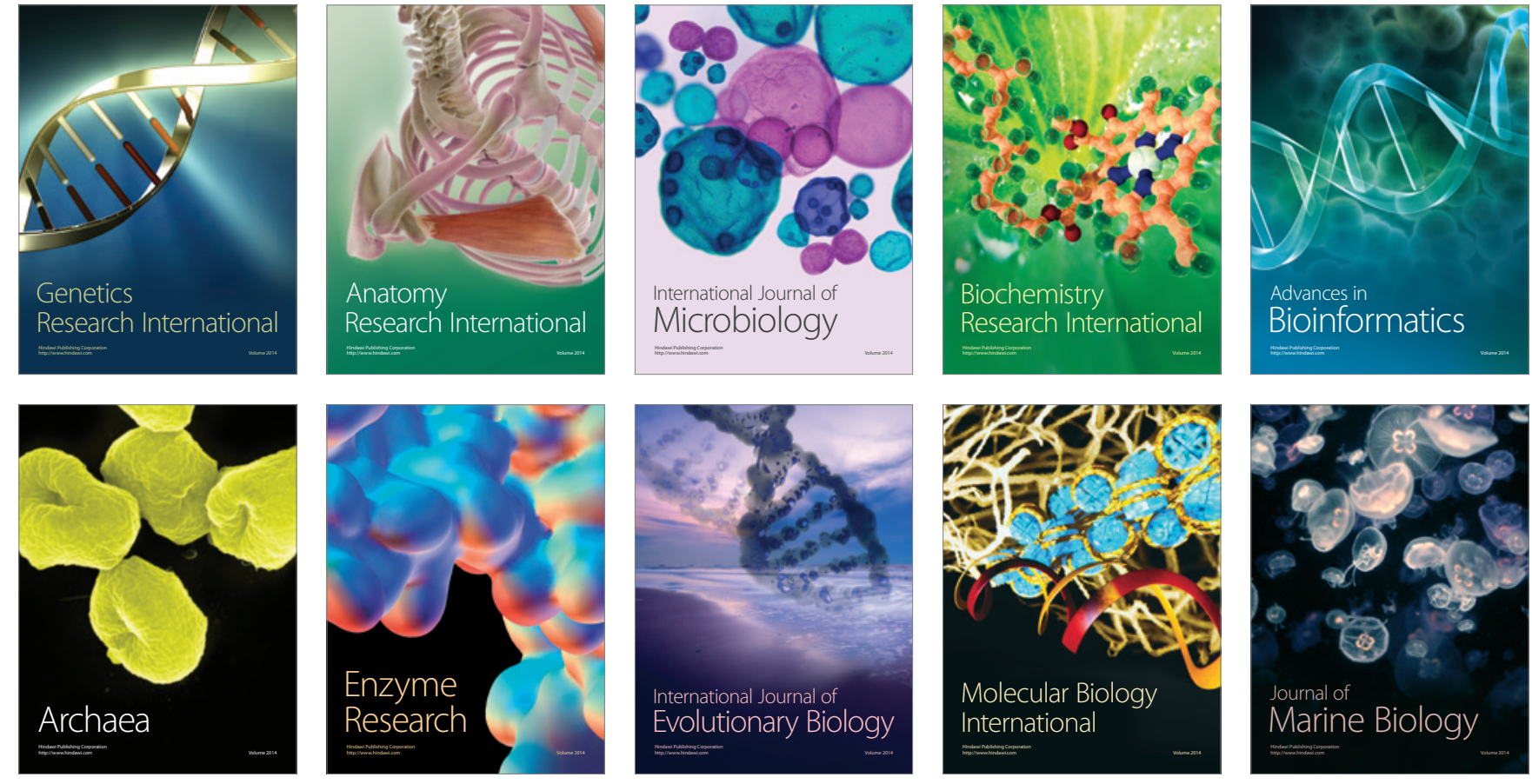